\title{
PODZIEMNY NURT MATERIALIZMU SPOTKANIA
}

\author{
LOUIS ALTHUSSER
}

\begin{abstract}
Abstrakt: W prezentowanym poniżej fragmencie Podziemnego nurtu materializmu spotkania Louis Althusser kreśli zarysy filozoficznej trajektorii określanej mianem „materializmu spotkania”. Charakterystyczną cecha proponowanego tutaj ujęcia jest nacisk na przygodność konstelacji organizującej warunki możliwości wydarzenia i jego trwania. Tekst stawia sobie za cel krytykę tradycji filozoficznej ujmującej materializm jako negatyw idealizmu, powielający jego strukturę i logikę myślenia; zaczyna się od analizy filozoficznych implikacji epikurejskiego atomizmu, by następnie przejść do omówienia motywu próżni i przygodności powtarzającego się u autorów takich jak Machiavelli, Spinoza, Rousseau, Marks czy Heidegger. Podziemny nurt materializmu spotkania został opublikowany pośmiertnie, w oparciu o materiały mające stać się podstawą nieukończonej książki. Tłumaczenie ukazało się dzięki uprzejmości l'Institut Mémoires de l'édition contemporaine (IMEC).
\end{abstract}

Słowa kluczowe: atomizm, clinamen, materializm, przygodność, Marks, Heidegger, Machiavelli, Spinoza, Hobbes, Rousseau 
Pada deszcz.

Niech będzie to zatem książka przede wszystkim o zwykłym deszczu.

Malebranche zastanawiał się: „dlaczego deszcz pada na morze, gościńce, piaski” (Malebranche 2006, 24-25) skoro ta spadająca z nieba woda, która gdzie indziej nawadniała całe kultury (z dużym skądinąd pożytkiem) nie dodaje niczego do stanu wód morskich lub wsiąka w drogi i piaszczyska.

Nie o taki jednak, opatrznościowy albo kontropatrznościowy, deszcz będzie nam tu chodzić.

W książce tej będzie mowa o innym deszczu, o motywie tworzącym głębinowy nurt przenikającym całą historię filozofii, zwalczanym, tamowanym już w momencie, gdy po raz pierwszy został sformułowany: to deszcz epikurejskich atomów, równolegle spadających w próżnię, „deszcz” nieskończonych, równoległych atrybutów Spinozy, deszcz Machiavellego, Hobbesa, Rousseau, Marksa, jak również Heideggera i Derridy. Oto zatem pierwsza rzecz, którą pragnę przedstawić, ujawniając już na początku moją główną tezę: $\mathrm{w}$ historii filozofii istnieje pewna, niemal całkiem zapoznana tradycja materialistyczna: „materializm” (przydałaby się skądinąd jakaś nazwa pozwalająca wyróżnić ją jako odrębną tendencję) - deszczu, odchylenia, spotkania, ujęcia'. Rozwinę wkrótce wszystkie te pojęcia. By sprawę uprościć powiedzmy na razie tyle: materializm spotkania, czyli materializm tego, co przypadkowe (aléatoire) i przygodne okazuje się myślą całkiem odmienną, czy wręcz przeciwstawną wobec innych materializmów, także wobec tego, który nagminnie imputuje się Marksowi, Engelsowi i Leninowi i który, jak cała tradycja racjonalistyczna, pozostaje materializmem konieczności i teleologii, to jest niczym innym, jak przekształconą i przebraną formą idealizmu.

Fakt, że ów materializm spotkania był przez tradycję filozoficzną tłumiony, nie wynika bynajmniej z tego, że nie został przez nią zauważony: był dla niej raczej zbyt niebezpieczny. Bardzo wcześnie zresztą zinterpretowano go, stłumiono i przenicowano w idealizm wolności. Bo jeśli atomy Epikura, które jako deszcz spadaja równolegle w próżnię, spotykają się, to czyż nie po to, byśmy w odchyleniu, które wytwarza clinamen rozpoznali istnienie ludzkiej wolności w świecie konieczności? Ta mylna i stronnicza

\footnotetext{
${ }^{1}$ Francuskie prise, będące rzeczownikiem odczasownikowym od prendre - brać - stanowi jeden z głównych terminów w teorii materializmu spotkania Althussera; to z pozoru proste pojęcie nastręcza jednak dużych trudności translatorskich. Rzeczownik prise - co słychać jeszcze w polskiej „pryzie” - to, dosłownie, naraz „wzięcie”, „chwyt” (uchwycenie), ale też „ujęcie” (w sensie teoretycznym). Poza tym wchodzi ono w liczne związki leksykalne, Althusser mówi, między innymi o „przyjęciu formy, kształtu”, „przejęciu” (np. władzy lub jednych elementów przez drugie) lub „włączeniu” (indywiduów w pewną całość), „zaistnieniu” („wzięciu się skądś”), „ścięciu” lub „zestaleniu” (zamarzającej wody albo kwaśniejącego mleka). Tłumacz wersji angielskiej używa wyrażenia take-hold, my, z uwagi na idiomatyczny charakter tych związków, stosujemy różne określenia, zaznaczając jednak w nawiasie, kiedy chodzi o ten termin (por. Althusser 2006) [ten i następne przypisy, jeśli nie zaznaczono inaczej, pochodzą od tłumacza].
} 
interpretacja wystarcza, by uciąć wszelkie inne odczytania owej stłumionej tradycji, którą nazywam materializmem spotkania. Idealistyczne wykładnie podtrzymują ten będący nieporozumieniem sąd, a nawet rozciagaja go dużo szerzej: to już nie tylko clinamen, ale Lukrecjusz w całości, a wraz z nim także Machiavelli, Spinoza, Hobbes, Rousseau z drugiej Rozprany, Marks, a nawet Heidegger, bo i on otarł się o tę tematykę. Interpretacją tą rządzi pewna koncepcja filozofii i jej historii, która - za Heideggerem - nazwać możemy zachodnia, skoro już od Greków ciąży ona nad naszym losem, a także logocentryczna, bo utożsamia filozofię z pewną funkcją Logosu, zobligowanego myśleć pierwszeństwo Sensu wobec wszelkiej rzeczywistości.

Wyzwolić ów stłumiony materializm spotkania, odkryć, co wnosi on zarówno do filozofii, jak do samego materializmu, rozpoznać ukryte jego efekty tam, gdzie oddziałuja w sposób milczaccy: oto zadanie, jakie chciałbym sobie postawić.

Zacznijmy od zestawienia, które może zdziwić: Epikur i Heidegger.

Epikur tłumaczy nam, że przed ukształtowaniem się świata nieskończoność atomów spadała równolegle w pustkę. Spadają one nadal. Wynika z tego jednocześnie, że nic nie poprzedzało świata i to, że wszystkie elementy świata istniały odwiecznie, zanim jeszcze zaistniał sam świat. Wynika stąd także, że przed ukształtowaniem świata nie istniał żaden Sens, żadna Przyczyna, Cel, Rozum czy nierozum. Nie-uprzedniość Sensu jest główną tezą Epikura, w której sprzeciwia się on tak Platonowi, jak Arystotelesowi. To, co się wydarza, to clinamen. Pozostawię specjalistom kwestię tego, kto pierwszy użył tego pojęcia, pojawia się ono jednak u Lukrecjusza, choć nie u Epikura i jeśli będziemy go używać w kontekście tego ostatniego, to dlatego, że wydaje się nam ono nieodzowne dla „logiki” jego tez. Clinamen to nieskończenie małe odchylenie, tak małe, jak to tylko możliwe, które ma miejsce „nie wiadomo kiedy ani jak” i które sprawia, że atom „odchyla się” względem toru swego spadania wprost w próżnię i - niemalże nie łamiąc zasady paralelizmu - prowokuje spotkanie z atomem sąsiednim i tak - od spotkania do spotkania - wywołuje masową kolizję, a z niej narodziny świata, czyli agregatu atomów, wywołanego łańcuchowo przez pierwsze odchylenie i pierwsze spotkanie.

Pomysł, że początek całego świata, czyli wszelkiej rzeczywistości jest wynikiem odchylenia, że to Odchylenie, a nie Rozum albo Przyczyna jest u początku świata, świadczy o śmiałości myślenia Epikura. Jaka filozofia, w całych filozoficznych dziejach, podjęła tezę, że odchylenie jest czymś źródłowym, a nie pochodnym? Trzeba jednak pójść jeszcze dalej. Aby odchylenie doprowadziło do spotkania, z którego rodzi się świat, trzeba aby trwało, aby nie było tylko „przelotnym”, lecz trwałym spotkaniem, które staje się tym samym podstawą wszelkiej rzeczywistości, wszelkiej konieczności, wszelkiego Sensu i rozumu. Równie dobrze spotkanie może jednak okazać się nietrwałe, wtedy zaś nie ma żadnego świata. Co więcej, widzimy, że spotkanie nie wytwarza realności świata, nie będącego niczym innym, niż 
konglomeratem atomów, ale że przydaje realności samym tym atomom, ponieważ bez odchyleń i spotkań są one jedynie abstrakcyjnymi elementami, pozbawionymi spójności i istnienia. Do tego stopnia, że można utrzymywać, że samo istnienie atomów bierze się właśnie $\boldsymbol{z}$ odchylenia $\boldsymbol{i}$ spotkania, bez których istniały one jedynie w sposób fantomowy. Da się to powiedzieć także innym językiem. Świat może być nazwany faktem dokonanym, w ramach którego, gdy już się dokonał, rządzić zaczyna Rozum, Sens, Konieczność i Cel. To spełnienie faktu jest jednak wyłącznie rezultatem czystej przygodności, ponieważ zależy ono od przypadkowego spotkania atomów, wynikającego z odchylenia clinamenu. Przed dokonaniem się faktu, przed wszelkim światem istnieje jedynie faktyczne nie-dokonanie, nieświat, będący tylko nierealnym istnieniem atomów.

Czym w takich okolicznościach staje się filozofia? Nie jest już amboną Rozumu i Początku rzeczy, ale teorią ich przygodności, jest rozpoznaniem faktu, faktu przygodności, rozpoznaniem tego, że konieczność jest przygodności podporządkowana, jest rozpoznaniem faktyczności form „nadających postać” skutkom spotkania. Mamy tu więc do czynienia z konstatacją: miało miejsce spotkanie i "pochwycenie” („prise”) jednych elementów przez drugie (w podobnym sensie, w jakim „chwyta” mróz). Kwestia Początku nie ma już znaczenia, podobnie jak wszystkie „wielkie pytania” filozofii: „dlaczego istnieje raczej coś, niż nic? Co jest początkiem świata? Jakie jest miejsce człowieka w porządku celów świata?”2 itd. Zapytam znowu - która z filozofii miała odwagę podjać te tezy?

Mówiliśmy o Heideggerze... i faktycznie, choć nie jest on przecież ani epikurejczykiem, ani atomista, znajdujemy u niego podobny ruch myśli. Wiemy wszyscy, że odrzuca on całkowicie kwestie Przyczyn i Celów świata. Znajdziemy tu jednak całą serię rozwiązań zogniskowanych wokół wyrażeń takich jak „es gibt”, ,jest/daje”, „,bycie danym tak oto”, kojarzących się z epikurejską inspiracją. ,jest/daje świata, materii, ludzi...”. Filozofia „es gibt”, „bycia danym tak oto” spłaca dług zaciagnięty przez klasyczne pytania o Początek itd. „Otwiera” ona także perspektywę przywracającą pewien rodzaj transcendentalnej przygodności świata, w który jesteśmy „,rzuceni”, i jego sensu, który odsyła do otwarcia Bycia, do pierwotnego pędu Bycia, jego „przesłania”, poza którym nie ma czego szukać ani myśleć. Świat jest więc dla nas pewnym „darem”, pewnym „faktem faktu”, którego nie wybraliśmy, i który „otwiera się” przed nami w faktyczności swojej przygodności, a nawet poza ta faktycznością, w tym, co nie jest jedynie konstatacja, ale „byciem-w-świecie”, które kieruje wszelkim możliwym Sensem. "Jestestwo jest strażnikiem bycia”. Wszystko mieści się w owym „to”. Co pozostaje zatem samej filozofii? Ponowne, tym razem w trybie transcendentalnym, stwierdzenie „bycia danym” i jego warunków, albo raczej jego skutków w ich nieprzekraczalnej daności.

\footnotetext{
${ }^{2}$ Althusser nawiązuje tu do Leibniza (por. Leibniz 1995, 103).
} 
Czy to w ogóle jeszcze materializm? To pytanie nie ma wiele sensu w odniesieniu do Heideggera, który umyślnie sytuuje się poza wielkimi podziałami i etykietami zachodniej filozofii. Czy zatem przynajmniej tezy Epikura uznać możemy za materialistyczne? Prawdopodobnie tak, bez wątpienia, ale tylko pod warunkiem, że zerwiemy najpierw z taką koncepcją materializmu, która, na bazie wspólnych im pytań i pojecć, czyni zeń odpowiedź na idealizm. Jeśli zatem mamy zamiar dalej mówić o materializmie spotkania, to głównie przez wzgląd na wygodę: należy jednak pamiętać, że także Heidegger się w nim mieści, a sam materializm spotkania wymyka się klasycznym kryteriom i właściwie wciąż czeka na odpowiednią nazwę.

Drugim z naszych świadków w tej historii podziemnej tradycji materializmu spotkania będzie Machiavelli. Jego projekt jest znany: myśleć, w niemożliwych okolicznościach szesnastowiecznych Włoch, warunki ustanowienia włoskiego państwa narodowego. Okoliczności podsuwałyby wzory Francji lub Hiszpanii - przykłady te pozostaja jednak $\boldsymbol{b e z} \boldsymbol{z}$ wiązku: podzielony, ale zapalczywy lud włoski, kraj pokawałkowany na małe państewka, zapomniane, przeklęte przez historię, upowszechniona, choć chaotyczna rewolta wszystkich przeciw obcej okupacji i grabieży; wreszcie silne, choć uśpione dążenie ludu do zjednoczenia, dążenie, o którym zaświadczają wszystkie wielkie dzieła epoki, nie wyłączając Dantego, który, choć co prawda nic ze spraw tych nie zrozumiał, również oczekiwał nadejścia „wielkiego Charta” (Dante 1977, 7-8), słowem: zatomizowany kraj, w którym każdy z jego atomów spada wolnym lotem nie spotykając nigdy atomu sąsiedniego. Należało zrobić zatem wytworzyć warunki dla pewnego odchylenia, a więc dla pewnego spotkania, z którego „wzięłaby się” (prenne) włoska jedność. Jak? Machiavelli nie wierzy, aby którekolwiek z istniejących państw, a zwłaszcza (opcja najgorsza z najgorszych) którekolwiek z Państw Kościelnych mogło odegrać rolę jednoczyciela. W Księciu wymienia je po kolei, ale tylko po to, by odsądzić je od czci, widząc w nich jedynie pozostałości dawnych, feudalnych stosunków produkcji - nie wyłączając republik, będących jedynie alibi względnie zakładniczkami owych stosunków. Machiavelli obnaża ten problem i wyraża go z całym rygorem.

Osądziwszy wszystkie państwa i ich książąt, czyli dokładniej - wszystkie miejsca i wszystkich Iudzi - posiłkując się przykładem Cezara Borgii, Machiavelli dochodzi do wniosku, że jedność może się zawiązać, o ile znajdzie się jakiś bezimienny człowiek, który miałby dość szczęścia, a także cnoty, by usadowić się gdzieś, w jakimś bę̧imiennym kącie Włoch i który począwszy od tego punktu-atomu zacząłby skupiać wokól siebie Włochów i włączać ich w wielki projekt budowy państwa narodowego. To całkowicie przypadkowe rozumowanie, które z imienia Zjednoczyciela (Fédérateur) i regionu mającego stać się 
zaczynem federacji czyni pewne polityczne in blanco. Tak właśnie padają kości na stół, który, choć sam pusty, otoczony jest ludźmi wielkiej wartości.

Aby spotkanie człowieka i krainy mogło się ,zawiązać” (prenne) musi ono mieć miejsce. Machiavelli, politycznie świadom ułomności konkurujących państw i rządzących nimi książąt, pytany o rzeczonego księcia i miejsce, milczy. Nie dajmy się temu zwieść. Ta cisza to polityczny warunek spotkania. W zatomizowanej Italii to właśnie na możliwość spotkania liczy Machiavelli, wyraźnie oczarowany wspomnianym Cezarem, który, zaczynając z niczym, zdołał przekształcić Romanię w królestwo i, podbiwszy Florencję, miał już połączyć całą Północ, gdyby tylko nie zachorował na bagnach Rawenny, w decydującym momencie swego buntowniczego marszu na rzymski dwór (i po tron) Juliusza II. Człłowiek z niçym, zaçynajacy znikad, zjakiegoś nie dajacego sie ustalić miejsca: oto, zdaniem Machiavellego, warunki odnowy.

Jednak by takie spotkanie mogło mieć miejsce, najpierw musi dojść do innego: do spotkania fortuny i cnoty (virtü) w osobie Księcia. Napotkawszy Fortunę Książę musi obejść się z nią jak z kobietą - przyjąć i uwieść albo wziąć ją siłą, słowem - wykorzystać ją dla realizacji swego przeznaczenia. To ze względu na tę myśl przypisujemy Machiavellemu autorstwo filozoficznej teorii spotkania między fortuną a cnota. Spotkanie może mieć miejsce lub go nie mieć. Zdarza się, że udaremnia je spóźnienie. Może być przelotne lub długotrwałe: tu potrzeba tego, które trwa. Książę musi też nauczyć się, jak zarządzać jednocześnie swoją fortuną i innymi ludźmi. Musi stworzyć strukturę państwa, ćwicząc w tym celu ludzi, zwłaszcza zaś dając im stałe prawa. Ludzi tych trzeba zdobyć wychodząc im naprzeciw, a jednocześnie zachowując swój dystans. Ten podwójny zabieg robi miejsce naraz dla teorii uwodzenia oraz teorii strachu, ale także dla teorii złudy. Pozostawiam na boku sprawę obalania miłosnej demagogii (Machiavelli 1972, 197-199) i przekonania, iż strach jest bardziej pożądany niż miłość (Machiavelli 1972, 193-196), a także kwestię gwałtownych metod, które mają strach wywoływać i przechodzę od razu do teorii złudy.

Czy książę powinien być dobrotliwy czy niegodziwy? Musi nauczyć się być niegodziwcem, a jednak zawsze, niezależnie od okoliczności, musi potrafić robić wrażenie dobrodusznego, musi posiadać zalety moralne, którymi zdobędzie lud, nawet jeśli sprowadzi to jednocześnie nienawiść możnych, którymi pogardza, bo i po nich nie można się spodziewać niczego innego niż pogardy. Znamy teorię Machiavellego: „książę powinien być jak znany starożytnym centaur - człowiekiem i bestią zarazem". Nie podkreślono jednak jeszcze, że w teorii tej już samo zwierze jest podwójine, jest lwem i lisem; i to lis jest tym, który ostatecznie rządzi (Machiavelli 1972, 197-199). Być raz dobrotliwym a raz niegodziwym, słowem: stwarzać się na wzór (ideologicznego) wyobrażenia ludu, odpowiadającego zainteresowaniu i interesom „maluczkich”, to zachowanie lisa. W ten sposób książę 
wewnętrznie podlega przekształceniom zachodzącym w obrębie tego drugiego, przypadkowego spotkania, spotkania lisa, z jednej strony, z lwem i człowiekiem z drugiej. To, że do spotkania tego może wcale nie dojść nie znaczy, że nie może do niego dojść. By figura księcia mogła „wziąć się” (prenne) z tego spotkania, musi być ono trwałe, a „wziąć się” to przyjąc formę, zostać instytucjonalnie uznanym za dobre i, jeśli to możliwe, być takim rzeczywiście, ale tylko pod absolutnym warunkiem, że książę potrafił będzie okazać swą niegodziwość, jeśli tylko zajdzie taka potrzeba.

Teorii tej nie można zamykać w obrębie filozofii politycznej - jest w niej filozofia w pełnym tego słowa znaczeniu. To właśnie „materializm spotkania”, ta osobliwa filozofia myślana poprzez politykę, która jako taka nie zakłada niczego przedustawnego. Do spotkania może dojść jedynie w politycznej pustce, którą winna „podjąć” (prendre) jedność narodowa. Ale ta pustka polityczna jest przede wszystkim pustką filozoficzną. Nie znajdziemy tu żadnej Przyczyny, która wyprzedzałaby swe skutki, żadnej Zasady moralności ani teologii (jak w całej arystotelesowskiej tradycji politycznej, z jej „dobrymi” i „złymi” ustrojami oraz staczaniem się pierwszych w drugie), nie rozumuje się tu w trybie Konieczności faktów dokonanych, ale w trybie kontyngencji faktów do dokonania. Jak w świecie epikurejskim, wszystkie elementy już się w niej zawieraja gotowe zaskoczyć, także tak, jak zaskakuje deszcz (patrz wyżej: sytuacja włoska), ale właściwie nie istnieja one jeszcze, pozostają abstrakcyjne, dopóki nie zjednoczą się i nie zaistnieją w formie spotkania.

Podkreślmy - filozofią tą rządzi alternatywa: spotkanie może mieć miejsce albo nie. Alternatywy tej nie rozstrzyga z góry żadna decydująca zasada - zachodzi ona jakby w trybie rzutu kośćmi, a „rzut kośćmi nigdy nie zniesie przypadku”. Istotnie! Nigdy udane spotkanie, nawet to długotrwałe, nie gwarantuje, że nie skończy się do jutra i będzie trwało dalej. Tak jak mogło nigdy nie mieć miejsca, tak też może nie mieć miejsca już więcej, „fortuna przemija i jest zmienna" - poświadcza Borgia, któremu wszystko się udaje, aż do głośnych dni jego choroby. Innymi słowy - nic nie gwarantuje, że rzeczywistość faktu dokonanego okaże się gwarancją jego wieczności, przeciwnie - każdy fakt dokonany, nawet elekcja (fait électora), przy wszelkiej racji i konieczności, jakie możemy mu przypisać, pozostaje jedynie prowizorycznym spotkaniem, które nawet jeśli trwa, nie gwarantuje nigdy wieczności „praw” rządzących jakimkolwiek światem czy państwem. Historia okazuje się zatem raczej nieustannym unieważnianiem dokonanego faktu przez inny fakt, będący dopiero do dokonania, nie dający się odszyfrować, nigdy nie wiadomo bowiem zawczasu ani gdzie, ani jak do takiego unieważnienia dochodzi. Pewnego dnia zwyczajnie okazuje się, że kości znów mogą być rzucone na pusty stół, rozpoczynając nowy przebieg gry. 
Zaznaczmy tym samym, że filozofia ta, w ogóle i w szczególe, jest filozofia próżni: nie tylko filozofią, która mówi, że istnienie próżni poprzedza istnienie spadających w nią atomów, ale także filozofią, która istnieje wytwarzając filozoficzną próżnię i zamiast wychodzić od słynnych „problemów filozoficznych” („dlaczego istnieje raczej coś niż nic?”) zaczyna od usunięcia wszystkich filozoficznych problemów, czyli odmowy wyznaczenia sobie własnego „przedmiotu”, jakim by on nie był („filozofia nie ma swojego przedmiotu”), by wyjść jedynie od niczego, od jego nieskończenie małego, przygodnego wahnięcia, stanowiącego odchylenie trajektorii spadania. Czy istnieje bardziej radykalna krytyka całej filozofii, z jej pretensja, by mówić jakimi rzeczy są naprawdę? Czy istnieje bardziej interesujący sposób, by rzec, że „przedmiotem” filozofii par excellence jest nicość lub pustka? W wieku siedemnastym wokół idei tej krażył Pascal i to on jako pierwszy uczynił pustkę przedmiotem filozofii - w pożałowania godny sposób przykroiwszy ją jednak do celów swej apologetyki. Także i w tym trzeba było doczekać Heideggera, zbywszy uprzednio fałszywe dyskursy Hegla („praca negatywności”) i Stirnera („swoją sprawę oparłem na nicości’ß), by oddać pustce jej decydujące, filozoficzne znaczenie. Znajdziemy ją jednak już u Epikura, a także Machiavellego, który przenicował wszystkie filozoficzne pojęcia Platona i Arystotelesa, by dzięki temu pomyśleć możliwość przekształcenia Italii w państwo narodowe. W ten sposób zmierzyć można również oddziaływanie filozofii, reakcyjne lub rewolucyjne, które wydobywać należy cierpliwie i z dbałością spod maski fałszujących pozorów.

Któż, czytając Machiavellego w ten sposób (a są to tylko wstępne uwagi, które mam nadzieję kiedyś rozwinaćc), sądziłby dalej, że chodzi tu tylko o politykę, a nie o autentyczna, wykraczająca poza zasięg polityki, myśl filozoficzną? Któż mógłby sądzić, że fascynacja, którą wzbudza Machiavelli, ma jedynie polityczny charakter, sprowadzający się do absurdalnej kwestii tego, czy był on raczej monarchistą, czy republikaninem (nawet najlepsza część filozofii oświecenia dała się złapać na to bzdurne pytanie), podczas gdy rezonans jego filozofii, czego on sam nie był świadom, jest najgłębszym brzmieniem docierającym do nas z tej pełnej cierpienia epoki? Chciałbym przemieścić ten problem, a zatem nie tylko odrzucić alternatywę monarchista/republikanin, nie mającą żadnego sensu, ale także potocznie przyjęte stanowisko, w myśl którego uznaje się Machiavellego jedynie za twórcę nauki politycznej. Chciałbym zasugerować raczej, że to nie polityczności, ale swoistemu „materializmowi spotkania” zawdzięcza Machiavelli oddziaływanie, jakie wywiera nawet na tych, którzy o politykę troszczą się tyle, co o zeszłoroczny śnieg (i słusznie zresztą, nikogo nie zmusza się, by „uprawiał politykę” i którzy po części dali się zwieść autorowi, na

\footnotetext{
${ }^{3}$ Stirner nawiązuje do wiersza Vanitas! Vanitatum vanitas Johanna Wolfganga Goethego (por. Stirner 1995, 3).
} 
próżno roztrząając, jak czynił to jeszcze Croce, skąd brać się może owa na zawsze niepojęta fascynacja.

Był jednak człowiek, który przeniknął naturę owej fascynacji, i to niecałe sto lat po śmierci Machiavellego. Nazywał się Spinoza. W Traktacie politycznym znajdujemy jawną pochwałę Machiavellego; jest to także tekst z filozoficzną stawką, choć wydawać by się mogło, że idzie w nim tylko o politykę. By ją zrozumieć, należy cofnać się jeszcze dalej, strategia filozoficzna Spinozy jest bowiem radykalna i niezwykle złożona. Wywalczał ja Spinoza w świecie pełnym, tłocznym, gdzie wrogowie, którzy opanowali cały teren (lub przynajmniej tak twierdzili) czujnie nasłuchiwali jego słów. Rozwija więc pewną problematykę zastępczą - która jednak z góry panuje nad wynikającymi zeń konsekwencjami.

Będę tu bronił tezy, że dla Spinozy przedmiotem filozofii jest pustka. Teza to, w kontekście całej masy wypracowanych w Etyce pojęć, paradoksalna (por. Spinoza 2008, 26). Spójrzmy jednak, skąd Spinoza zaczyna. Wyznaje w liście: „niektórzy zaczynają od świata, niektórzy od umysłu, ja zaczynam od Boga”. Ci „niektórzy” to z jednej strony scholastycy, zaczynający od badania świata stworzonego, które wznosi ich do Boga, z drugiej strony Kartezjusz, który wychodzi od myślącego podmiotu (cogito) by dojść zaraz do podmiotu wattpienia (dubito), a stąd do Boga - słowem: Bóg dla nich wszystkich okazuje się punktem dojścia. Spinoza zna ekonomię tych zabiegów - dlatego celowo i świadomie od początku usadawia się $\boldsymbol{w}$ Nim. Możemy więc powiedzieć, że już w pierwszym kroku wznosi on pewną wspólną fortecę (la place forte commune), będąca jednocześnie ostateczną gwarancją i decydującym odporem wszystkich jego wrogów. Czyni to, zaczynając od tego, poza czym nie istnieje nic, czyli od tego, co istniejąc w sposób absolutny, to jest poza jakąkolwiek relacją, samo jest niczym. Powiedzieć „zaczynam od Boga”, albo „od Całości” i sugerować: „zaczynam od Niczego” to ostatecznie jedno i to samo - jaka jest bowiem różnica między Wszystkim i niczym? Skoro nic nie istnieje poza Wszystkim... Cóż jednak mówi się w ten sposób o Bogu? Tu zaczyna się robić dziwnie.

Bóg nie jest niczym innym, niż natura (Dieu n'est que nature), co sprowadza się do stwierdzenia, jest on niczym innym, niż naturą (il n'est que nature). (Również Epikur zaczynał od natury, jako od tego, na zewnątrz czego nic nie istnieje.) Kim więc jest ów spinozjański Bóg? Substancją absolutną, jedyną i nieskończoną, wyposażoną w nieskończoność nieskończonych atrybutów. Oczywiście, w pewien sposób mówi się tym samym, że nic co istnieje, nie istnieje gdzieś indziej, niż w Bogu (niezależnie od tego czy to „coś” albo „gdzieś” byłoby nam w ogóle znane). Poznajemy bowiem jedynie dwa z atrybutów, rozciagłość i myślenie, i nawet w samym ciele nie jesteśmy zdolni rozpoznać wszystkich jego zdolności (Spinoza 2008, 146), tak jak nie rozpoznajemy wszystkich 
zdolności myśli, wymyka się nam bowiem niemyślana zdolność pragnienia. Nieskończona ilość innych, nieskończonych atrybutów jest tu po to, by mieściło się w nich wszystko, możliwe i niemożliwe. Fakt, że jest ich nieskończoność, i że pozostaja nam nieznane, pozostawia otwartą kwestię ich istnienia i przypadkowych postaci, jakie przyjmuja. Ich równoległość, fakt że wszystko jest w nich skutkiem paralelizmu, każe z kolei myśleć o epikurejskim deszczu. Atrybuty spadają w głąb pustej przestrzeni swojego nieokreślenia, jak krople deszczu, nie spotykające się nigdzie indziej, jak tylko w owym wyjątkowym paralelizmie, paralelizmie bez spotkania ani unii (ciała i duszy) która jest człowiek; spotykają się w owym ledwie zauważalnym paralelizmie, który jednak nadal pozostaje paralelizmem, skoro i w nim, tak jak i we wszystkich innych rzeczach, „porządek i związek idei jest taki sam jak porządek i związek rzeczy"(Spinoza 2008, 71). Podsumowując - jest to paralelizm bez spotkania, który jednak sam w sobie jest spotkaniem, ze względu na relacyjną strukturę elementów wewnątrz każdego atrybutu.

By jednak wydać tu jakiś sąd, należy dostrzec filozoficzne skutki tej strategii i takiego paralelizmu. Fakt, że Bóg jest niczym innym, jak tylko naturą i że sama ta natura jest nieskończoną sumą wszystkich nieskończonych, paralelnych atrybutów sprawia nie tylko, że na temat Boga nie ma juź nic do dodania, ale także to, że nie pozostaje już nic do powiedzenia na inny wielki temat, który nękał zachodnią filozofię od Arystotelesa, a zwłaszcza od Kartezjusza, to jest problem poznania, wraz z jego podwójnym korelatem poznającym podmiotem i poznawanym przedmiotem. Poważne racje tej problematyki, przyczyniające się do tak wielu dyskusji, okazują się niczym; „homo cogitat”, „człowiek myśli” (Spinoza 2008, 65) stwierdza jedynie pewną faktyczność, w rodzaju ,jest tak oto”, „es gibt” - co ogłasza już Heidegger, przywołując właśnie faktyczność upadania atomów Epikura. Myślenie to tylko następstwo pobudzeń atrybutu myślenia, które nie odnosi się wcale do żadnego Podmiotu, ale - jak na paralelizm przystało - do następstwa pobudzeń w atrybucie rozciąłości.

Interesująca jest również kwestia tego, jak dochodzi do ustanowienia ludzkiego myślenia. Pierwsze myśli są mętne, to myśli, które pozostaja „pogłoskami”, dopóki nie „przyjmą” („prendre”) formy i nie dadzą się pomyśleć już jako „pojęcia wspólne” (to droga wiodąca od pierwszego do drugiego poziomu poznania; do trzeciego dochodzi się przez „istoty jednostkowe”) (Spinoza 2008, 118). Istotne jest to, że człowiek może pozostać na poziomie pogłoski - tym samym „przyjęcie” poznania niższego, poznania pierwszego poziomu przez myśli z poziomu drugiego nie miałoby miejsca. To los większości ludzi, którzy pozostaja na pierwszym poziomie, na poziomie wyobrażeń, czyli iluzji myślenia (podczas gdy tak naprawdę nie myślą wcale). Tak jest. Można zostać na pierwszym poziomie poznania bądź nie zostawać tam. Nie ma tu jednak wcale, jak u Kartezjusza, immanentnej konieczności, która przenosiłaby myślącego od myśli ułomnej do jasnej i wyraźnej, nie ma 
„cogito”, nie ma koniecznego momentu refleksji, który by przejście to gwarantował. Do niego także może dojść lub nie dojść. I, jak wskazuje doświadczenie, na ogół rzeczywiście nie dochodzi, poza wyjątkowym przypadkiem takiej filozofii, która jest świadoma swej nicości.

Co zatem pozostaje zadaniem filozofii, skoro przenicowała ona Boga i teorię poznania, których to funkcją było wytwarzanie „wyższych wartości”, mających dostarczać kryteriów? Już nie moralność i przede wszystkim nie religia - w zamian za nie taka teoria moralności i religii, która burzy je aż do ich wyobrażonych i „odwróconych” fundamentów, tej fabrica na opak (por. Dopełnienie księgi I Etyki; Spinoza 2008, 55), i już nie celowość (czy to psychiczna, czy historyczna), słowem - pustka, która jest samą filozofią. Skutek ten jest wynikiem gigantycznej pracy pojęciowej, na której skoncentrowany jest cały wysiłek Etyki; pracy „krytycznej” jak mówi się potocznie; pracy „dekonstrukcji”, jak za Heideggerem powie Derrida, ponieważ to, co zostaje zniszczone, odtwarza się, ale już na innych podstawach i wedle całkiem innego planu, zaświadczając o niewyczerpywalnej teorii wyobraźni lub wyobrażonego, która naraz niszczy i rekonstruuje teorię wiedzy, teorię religii, teorię historii, itd., o ile ujmuje się je z punktu widzenia ich rzeczywistych funkcji politycznych.

Mamy skłonność przedstawiać tę nietypową teorię jako teorię poznania (pierwszego $z$ trzech jego poziomów), podczas gdy wyobraźnia nie jest wcale, w żadnym stopniu, władzą umysłu, ale z gruntu niczym innym, niż samym, jedynym światem, w formie, w jakiej jest „dany”. Dzięki temu przesunięciu Spinoza unika nie tylko wszelkiej teorii poznania, ale otwiera także perspektywę uznania (reconnaissance) świata, jako tego, poza czym nie ma nic, którego nie przekracza żadna teoria natury, perspektywę uznania „świata” jako jedynej całości, nie będącej jednak totalnością, ale przeżytej w swym własnym rozproszeniu, w swej „danej” postaci, w która jesteśmy „wrzuceni” i wychodząc od której wytwarzamy wszystkie swe iluzje (,faricae”). W gruncie rzeczy teoria zrównująca „pierwszy poziom poznania” ze „światem” odpowiada w sposób odległy, lecz dokładny tezie mówiącej o „Bogu jako naturze”, naturze nie będącej niczym innym, jak światem myślanym według pojęć wspólnych, ale danym najpierw, przed nimi, jako to, poza czym nie ma nic innego. To w wyobraźni świata, w jego nieodzownych mitach zaszczepia się polityka Spinozy, który w swych najbardziej zasadniczych wnioskach łączy się z Machiavellim, powtarzając jego gest wykluczenia wszelkich założeń tradycyjnej filozofii, uznaniu autonomii polityki jedynie za formę przyjmowaną za sprawą odrzucenia wszelkiej religii i wszelkiej transcendencji. Jednocześnie jednak teoria wyobraźni jako świata pozwala Spinozie pomyśleć ową „pojedynczą istotę" należącą do trzeciego poziomu poznania, znajdująca swoje przedstawienie par excellence w historii jednostki albo ludu, jak choćby w przypadku Mojżesza i Żydów. Fakt, że jest ona konieczna znaczy tyle, że już się wydarzyła, ale wszystko, co ja 
tworzy mogło potoczyć się inaczej, w zależności od spotkania Mojżesza z Bogiem (lub ich niespotkania), zrozumienia bądź niezrozumienia słów proroków. Dowodem jest fakt, że trzeba było tłumaczyć ludowi to, co donosili prorocy o swych spotkaniach z Bogiem! Sytuacją graniczną (czy wręcz „przenicowana”) jest sytuacja Daniela, któremu wszystko dokładnie tłumaczono, a i tak nigdy nic nie zrozumiał (Spinoza 2000, 103); dowód nicości, wyprowadzony z samej nicości jako sytuacja graniczna.

Hobbes, ten „diabeł” i „demon” wytyczy drogę przejścia między Spinozą a Rousseau. Chronologia nie znaczy tu wiele, bo każda z tych myśli rozwijała się „dla siebie samej”, mimo pośredniczącej roli Mersenne'a, a także z tego względu, aby wybrzmiał i dał się usłyszeć rezonans tej pogrzebanej i wskrzeszonej tradycji, o której mówimy. Każde społeczeństwo opiera się na strachu, czego empirycznym dowodem jest to, że wszyscy nosza klucze - a po co? - po to, by uchronić swój dom przed wtargnięciem nieznajomych, czy będa to sąsiedzi, czy najlepszy przyjaciel, którego nasza nieobecność, okazja i żądza wzbogacenia się przemieniły w „wilka w ludzkiej skórze”. Z tej zwięzłej uwagi, wcale nie mniej znaczącej niż nasze „analizy istot”, wyprowadza Hobbes całą swą filozofię, a zwłaszcza przekonanie, że między ludźmi zachodzi „wojna wszystkich ze wszystkimi”, „niekończący się wyścig”, w którym każdy chce wygrać, ale niemal każdy przegrywa, gdzie wszyscy mierzą swą pozycję względem konkurentów (stąd traktat „o namiętnościach” - pisany skądinąd zgodnie z ówczesnym zwyczajem kamuflowania treści politycznych) wyprzedzających, wyprzedzanych, i tych, z którymi idzie się równo. Tu właśnie źródło ma idea powszechnej wojny - nie tej, która wybucha między państwami (jak konsekwentnie utrzymywać będzie Rousseau), ale tej, której groźba wisi nad ludźmi jak pogarszająca się pogoda (gdy rozpadać się może w każdym momencie, w dzień czy w nocy, bez ostrzeżenia), krótko mówiąc - jak permanentna groźba wymierzona w życie i własność człowieka i jak groźba śmierci, która wisi zawsze i nad każdym, z tego tylko powodu, że żyje on w społeczeństwie. Jestem świadom, że Hobbes myśli o czymś innym niż, jak utrzymywano, zwykła konstrukcja ekonomiczna. Chodzi mu raczej o wielkie bunty, których był świadkiem (nie można pozostać obojętnym, gdy jest się współczesnym Cromwella i egzekucji Karola I) i na przykładzie których widział, jak mały strach właścicieli kluczy ustępuje przerażeniu wywołanemu przez ludowe rewolty i polityczne morderstwa. To zwłaszcza o tym strachu mówi Hobbes, przywołując ów nieszczęsny czas, kiedy jedna część społeczeństwa zdolna była dokonać mordu na drugiej, by odebrać jej władzę.

Hobbes - porządny teoretyk prawa naturalnego - nie zatrzymuje się oczywiście na poziomie tych pozorów, jakkolwiek nie byłyby one przerażające; chce raczej, wychodząc od skutków, dojść do przyczyn - to dlatego proponuje pewną teorię stanu naturalnego. By 
zanalizować ją w jej podstawowych elementach, należy dojść do „atomów społeczeństwa”, to jest jednostek wyposażonych $\boldsymbol{w}$ conatus, czyli władzę i wolę „utrzymania się w istnieniu”; trzeba wytworzyć wokół nich pewną pustkę, będąca przestrzenią ich wolności. Jednostkiatomy, pustka jako warunek ich ruchu, czy czegoś nam to nie przypomina? Hobbes uznaje, że wolność, która „stanowi” jednostkę i jej moc istnienia, utrzymuje się w pewnej pustce, rozumianej jako „brak przeszkód” na drodze jej podbijającej siły. Odwołanie do wojny wszystkich ze wszystkimi jest dla Hobbesa tylko wybiegiem, usuwającym wszelkie przeszkody, które przeszkadzałyby mu iść naprzód (myślimy stale o wolnym, równoległym spadaniu atomów) i byłby on najszczęśliwszy, gdyby nigdy nie spotkał człowieka w świecie, tym samym pustym. Pech chce jednak, że świat ten jest pełen, pełen ludzi zmierzających do osiagnnięcia tych samych celów. Konfrontują się oni zatem nieustannie, aby wywalczyć puste miejsce dla swego conatusu, i dla realizacji swoich celów nie znajdują innych środków, niż „zadawanie śmierci” każdemu, kto zagrodzi im drogę. Stąd zasadnicza rola, jaką w swym myśleniu nieskończonego życia przyznaje Hobbes śmierci, ale nie śmierci przypadkowej, tylko koniecznej, z konieczności zadanej ręką innego człowieka, rola śmierci ekonomicznej i politycznej, jedynej zdolnej utrzymać to społeczeństwo wojny w stanie niestabilnej, ale koniecznej równowagi. Ci przerażający ludzie pozostaja jednak ludźmi, myślą, to znaczy kalkulują, ważąc korzyści wynikające z pozostania w stanie wojny lub przejścia do stanu państwowego, gdzie obowiązuje umowa, stanu który jednak wciąż opiera się na tym samym, „niezbywalnym” fundamencie: strachu i terrorze. Rozumując w ten sposób dochodzą oni do wniosku, że korzystnym będzie zawrzeć szczególnego rodzaju pakt, który zaburzy równowagę, na mocy którego jednak jednostki-atomy zgadzają się między sobą, że nie należy stawiać oporu wszechwładzy tego, na rzecz którego zrzekną się, jednostronnie i bez żadnego „pokwitowania” wszystkich swych praw (naturalnych) - czyli władzy Lewiatana, czy byłaby nim jednostka, jak w monarchii absolutnej, czy wszechmocne zgromadzenie ludowe lub reprezentujące lud. Jednostki te zobowiązuja się (i siebie nawzajem) do poszanowania owej delegacji władzy i lojalności wobec niej, pod groźba straszliwych sankcji nakładanych przez Lewiatana, który, zauważmy, ze swej strony nie jest związany z ludem żadną umową, ale utrzymuje jego jedność poprzez egzekwowanie swej udzielonej mu jednogłośnie wszechwładzy, przez strach i terror panujące na obrzeżach prawa, a także przez własne poczucie obowiązku (czyż to nie cud, że się tak poczuwa?), które każe mu utrzymywać lud w poddaństwie, by oszczędzić mu koszmarów stanu wojny, nieskończenie okropniejszych niż strach. Książę, którego ze swym ludem nie łączy nic poza obowiązkiem powstrzymania wojny, lud, którego z Księciem nie wiąże nic, poza obietnicą (dotrzymana, albo ratuj się kto może!) całkowitego posłuszeństwa, włącznie ze zgodnością ideologiczną (Hobbes jest pierwszym, który - na tyle, na ile to możliwe - pomyślał dominację ideologiczną wraz z jej skutkami) - oto oryginalność, ale i straszność tego wywrotowego myśliciela, który wyciagną 
słuszne wnioski, choć rozumował kiepsko, jak powie Kartezjusz - którego racje były fałszywe, myśliciela poza wspólnotą, którego nikt nie rozumiał, ale bał się każdy. Myślał (a przywilejem myślenia jest to, że nie potrzebuje zawracać sobie głowy tym, co ludzie mówią, pogłoskami, nawet własną reputacja; to przywilej myślenia w absolutnej samotności, a przynajmniej w jej złudzeniu) - jakie znaczenie mogły więc mieć oskarżenia, którymi (podobnie zreszta jak Spinozę) próbowano go dosięgnąc - zarzuty, jakoby był posłańcem Piekła i Diabła między ludźmi, itd. Hobbes sądził, że każda wojna jest prewencyjna, że każdy - wobec Innego - może jedynie starać się wziąć nad nim górę. Hobbes utrzymywał - i to jak zaciekle! - że wszelka władza jest absolutna, że absolutny byt jest istotą władzy i że wszystko, co choćby odrobinę, czy to z prawa, czy z lewa, wykracza poza tę regułę, powinno być z całym rygorem tępione.

$[\cdots]$

Świadom jestem, że naciagam tu myśl, która sama nigdy nie poszła tak daleko, pozostaję jednak na gruncie jej wewnętrznej logiki i zdaję sprawę z jej paradoksów w zgodzie z tą logiką. Jakby nie było, pewnym jest, że Hobbes nie był takim monstrum, jakim się go przedstawia, i że jego jedyną ambicją było zabezpieczenie warunków realizacji i rozwoju pewnego świata, który był tym czym był, był jego światem, światem renesansu, otwierającym się na niesłychane odkrycia Nowego Świata.

Oczywiście, „pochwycenie” (,prise”) zatomizowanych jednostek nie ma u Hobbesa tej samej natury i rozmachu, co u Machiavellego. Poza tym, choć sam przeżył spory kawałek historii, to, niestety, nie był historykiem (nie jest to wokanda, którą można sobie po prostu nadać), ale na swój własny sposób doszedł on do tych samych konkluzji, co jego mistrzowie należący do tradycji materializmu spotkania: do stwierdzenia przypadkowej natury procesu konstytuowania światów, i jeśli wywarł on taki wpływ na Rousseau (jeszcze o tym powiemy), a nawet na Marksa, to właśnie ze względu na podjęcie owej tradycji, nawet jeśli, co wcale niewykluczone, nie był tego świadom. Ostatecznie wiemy, że świadomość w tych sprawach jest raczej dodatkiem; liczy się, aby zaprzęg ciagnął powóz świata, galopem przez równiny albo z mozołem pod górkę.

To Rousseau i jego drugiej Rozprawie, a także Rozprawie o pochodzeniu języków, zawdzięczać można podjęcie kwestii materializmu spotkania.

Nie zaznaczyliśmy jeszcze dość wyraźnie, że druga Rozprawa zaczyna się od opisu stanu naturalnego, odróżniającego się od innych tego typu opisów tym, że stan natury dzieli się na dwa: „stan czystej natury” (Rousseau 1956, 140-141) będący radykalnym Początkiem 
wszystkiego i „stan natury” wynikający z modyfikacji, którym ulega ten stan czysty. We wszystkich przykładach stanu natury, jakie opisywane sa przez autorów koncepcji prawa naturalnego, ów stan zawsze jest już pewnym stanem społecznym (pokoju albo wojny wszystkich przeciw wszystkim); projektują oni, co zresztą Rousseau im wyrzuca, stan społeczny na stan czystej natury. Rousseau jest jedynym, który myśli stan czystej natury jako stan bez żadnej relacji społecznej, pozytywnej bądź negatywnej. Jego wyobrażenia dostarczaja nam fantastyczne obrazy pierwotnego lasu (które każą myśleć o innym Rousseau, zwanym Celnikiem), obrazy lasu, w którym błądzą odosobnione jednostki, nie nawiązując z sobą żadnych relacji, jednostki bez spotkania. Jasne, możliwe jest oczywiście, że jakaś kobieta i jakiś mężczyzna wejda w „przelotne obcowanie”, pieszczotę, a nawet złączą się w parę, spotkania te pozostaja jednak epizodyczne, nie tworzą tożsamości i nie znajduja uznania: ledwie się spotkali, już się od siebie oddalają (a o dzieciach nie mówi się wcale, tak jakby przed Emilem ludzki świat w ogóle nie zauważał ich istnienia albo mógł się bez nich obyć a skoro bez dziecka, to także bez ojca, matki, słowem: rodziny w ogóle) i każde podąża dalej swoją ścieżka przez pustą nieskończoność lasu. Przez większość czasu nie można w ogóle mówić o spotkaniu - dwoje ludzi mija się jedynie z mniej lub bardziej daleka i nawet nie zdając sobie z tego sprawy. Las jest odpowiednikiem epikurejskiej pustki, w którą spada równoległy deszcz atomów: to pustka psedo-brownowska ${ }^{4}$, gdzie jednostki tylko natykają się na siebie, co znaczy tyle, że właściwie nie spotykają się, chyba że przypadkowo, przelotnie i bez perspektywy trwania. W ten sposób Rousseau chciał nadać kształt (zresztą za bardzo wysoką cenę, jaką jest nieobecność dzieci) pewnej pustce społecznej, wcześniejszej od wszelkiego społeczeństwa, oraz jego warunkom możliwości, społecznej pustce, która konstytuuje istotę każdego możliwego społeczeństwa. To, że społeczna pustka staje się istotą społeczeństwa, jest tezą brawurowa, której radykalność umykała nie tylko jej współczesnym, ale także wielu późniejszym komentatorom.

Czego zatem potrzeba, aby rzeczywiście zaistniało społeczeństwo? Trzeba, aby stan spotkania został narzucony ludziom, aby nieskończoność lasu, jako warunek możliwości braku spotkania, sprowadzona została do skończoności za sprawa przyczyn zewnętrznych katastrofy naturalne kawałkuja go na mniejsze obszary, jak choćby wyspy, gdzie ludzie zostaja zmuszeni do spotkań, i to tych, które trwają: zmuszeni przez jaką́s siłę, która ich przewyższa. Przemilczę wynalazczość samych tych oddziałujących na powierzchni Ziemi katastrof, z których najprostszym i najlżejszym jest nieznaczne odchylenie równika wobec ekliptyki (przypadek, którego przyczyn nie można jednak porównywać z clinamenem) - i przejdę od razu do ich skutków. Raz zmuszeni do spotkania i stowarzyszenia, które faktycznie trwaja, ludzie widzą, jak rozwijają się między nimi przymusowe relacje, będące już relacjami

\footnotetext{
${ }^{4}$ Althusser odwołuje się tutaj do tzw. ruchów Browna wyjaśniających drganie cząsteczek zawiesiny w płynie [przyp. red.].
} 
społecznymi, zrazu rudymentarnymi, które wzmocnione zostaja przez skutki, jakie owe spotkania zdołały już w ludzkiej naturze wywołać.

W tym punkcie do gry wchodzi cała długa i powolna dialektyka: wraz z upływem czasu przymusowe stosunki wytwarzają język, namiętności, miłosne wymiany (commerce ammoreux) i walki między ludźmi: $z$ wojną włącznie. Powstanie stanu społecznego jest powstaniem stanu natury i jednocześnie stanu wojny; wraz z nimi rozpoczyna się proces akumulacji i modyfikacji, która dosłownie kreuje społeczną naturę człowieka. Zauważymy, że owo spotkanie mogłoby nie trwać nawet chwili, gdyby zewnętrzne ograniczenia nie utrzymywały go w ryzach $i$ nie oddalały pokusy rozproszenia, gdyby dosłownie nie narzuciły mu swojej zasady zbliżania, bez pytania ludzi o zdanie, zawiązując społeczeństwo niejako za ich plecami. Historia to „grzbietowe”, nieświadome konstytuowanie się tego społeczeństwa.

Bez wattpienia człowiek w stanie czystej natury, posiadacz ciała, ale, jak się zdaje, nie duszy, ma zdolność transcendująca wszystko, co istnieje i się przydarza - zdolność samodoskonalenia - która jest niczym abstrakcja i transcendentalny warunek możliwości antycypacji jakiegokolwiek rozwoju. Ponadto, co być może jeszcze ważniejsze, charakteryzuje go także litość, negatywna zdolność do (unikania) cierpienia cierpieniem bliźnich, społeczność w nieobecności (société par manque), ukryty negatyw społeczności w wyizolowanym człowieku, wciąż spragnionym obecności Innego w swojej samotności. To wszystko jednak, założone już w stanie czystej natury, tak naprawdę nie działa ani nie skutkuje w niej jeszcze, jest tylko oczekiwaniem nadchodzącej przyszłości. Tak jak społeczeństwo i jego historia powstaja za plecami człowieka, bez jego świadomego i aktywnego udziału, tak samodoskonalenie i litość są jedynie pustą antycypacją owej przyszłości, gdzie człowiek będzie po nic.

Nawet jeśli przemyślano już genealogię tych pojęć (Goldschmidt poświęca jej wyczerpujące studium), na pewno nie przemyślano jeszcze wystarczająco skutków owego urządzenia, którego opis zamyka w drugiej Rozprawie teoria umowy nieuprawnionej (Rousseau 1956, 214), kontraktu siłowego, przeforsowanego dzięki posłuszeństwu słabych i arogancji silnych, będących jednocześnie najbardziej „chytrymi”. To tu tkwi właściwy sens umowy społecznej, która zawiązuje się i obowiązuje jedynie za cenę nieustanego zagrożenia otchłanią (l'abîme - słowo, którego używa sam Rousseau w Wyznaniach), prowadzącą do nawrotu stanu natury, niczym organizm, stale zagrożony śmiercią, która zagraża mu od wewnątrz i którą musi odpędzać, krótko mówiąc - spotkanie, które przybrało (a pris) formę i stało się koniecznością, ale na przypadkowym gruncie niespotkania i właściwych mu form, sprawiających, że umowa może w każdej chwili ponownie się załamać. Uwagę tę należałoby rozwinąć, ale jeśli nie jest fałszywa, to rozwiązuje ona klasyczną aporię, nieustępliwie przeciwstawiająca Umowę drugiej Rozprawie, tę akademicką zagwozdkę, 
której odpowiednikiem w historii zachodniej kultury są chyba tylko niedorzeczne domniemywania na temat monarchizmu albo republikanizmu Machiavellego. Rozjaśniłaby ona tym samym status tekstów, w których Rousseau porywa się na projektowanie praw obcych ludów, Korsykan, Polaków, itd., podejmując, z całą jego wagą, pojęcie, które dominuje u Machiavellego - choć nie używa tego słowa, co jednak nie ma znaczenia, skoro idzie o to samo - pojęcie koniunktury: by nadawać prawa ludziom, trzeba być w najwyższym stopniu świadomym, jak wyglądaja realia, pewne tak, a nie inaczej, jak u Monteskiusza piszącego alegorycznie o klimacie i wielu innych warunkach, decydujących o historii ludów, to znaczy ich „byciu w stawaniu się” (êtredevenu), słowem - być świadomym ich spotkań, które mogłyby nie mieć miejsca (por. stan naturalny jako „stan, który mógł nigdy nie zaistnieć”), ale które jednak miejsce miały i kształtowały „dane” problemu oraz jego stan. O czym to świadczy, jeśli nie o przygodności konieczności i - będącej jej źródłem - konieczności przygodności? Umowa społeczna, w swojej prawomocnej bądź nieprawomocnej formie nie jawi się już zatem jako utopia, ale jako wewnętrzne prawo każdego społeczeństwa. Prawdziwy problem jest zatem następujący: jak to możliwe, że nie podnosi się nigdy pewnej nieprawomocnej (zwyczajowej) formy do rangi formy prawomocnej? Ta pierwsza, ostatecznie, nie istnieje, ale należy ją założyć, aby móc pomyśleć konkretne istniejące formy, spinozjańskie „,istoty jednostkowe”, czy to jako jednostki, czy zbiegi okoliczności (conjonctures), realne państwa lub ich ludy; formę tę należy zatem uznać za warunek transcendentalny wszelkiej kondycji (condition transcendantale de toute condition), to jest - wszelkiej historii.

Odkryte i ponownie zakryte jest tu to, co stanowi bez wattpienia najgłębszą myśl Rousseau: ujęcie wszelkiej możliwej teorii historii od strony myślenia przygodności konieczności, jako wynikającej z konieczności przygodności (ta para pojęć może tu zbijać z tropu, a jednak ma kluczowe znaczenie). Myśl ta pączkuje u Monteskiusza i uzyskuje formę wyraźnego postulatu u Rousseau jako zrodzona przez wiek osiemnasty intuicja odrzucająca wszelką pokusę teleologizowania historii, myśl, której drzwi otworzy na oścież niepohamowany impet Rewolucji Francuskiej. Jeśli ujać to w terminach polemicznych, rzec można, że w jednym obozie ustawiają się Epikur, Spinoza, Monteskiusz i Rousseau, opierając się, skrycie lub otwarcie, na tym samym materializmie spotkania, albo, w mocnym sensie, teorii koniunktury i przeciwstawiając się tym, którzy mówią o celu/końcu historii (la fin de l’histoire). W obozie tym jest również, oczywiście, Marks, zmuszony myśleć w perspektywie rozdarcia między przypadkowością Spotkania i koniecznością Rewolucji.

Spróbujmy zaryzykować jeszcze jedną uwagę, która usiłowałaby wskazać, że być może nieprzypadkowo owa szczególna para pojęć interesowała przede wszystkim tych, którzy za pomoca „spotkania” i „koniunktury” próbowali myśleć nie tylko realność historii, ale przede wszystkim polityki, nie tylko istotę rzeczywistości, ale przede wszystkim praktyki, a także więź tych dwóch istot, czyli ich spotkanie: w walce, a więc ostatecznie wojnie 
(Hobbes, Rousseau), w walce o uznanie (Hegel), ale także, wcześniej, w wojnie wszystkich przeciw wszystkim, czyli konkurencji, albo w walce klas (i ich „sprzeczności”). Czy trzeba przypominać dlaczego (i dla kogo) Spinoza nawiązuje do Machiavellego? Chce on jedynie myśleć dalej jego myśl, a jako że jest ona myśleniem praktyki, chce myśleć praktykę poprzez myśl.

Wszystkie te uwagi historyczne są tylko wstępem do tego, co chciałbym spróbować powiedzieć na temat Marksa. Nie są one w żadnym razie przypadkowe, świadczą bowiem o tym, że od Epikura do Marksa prowadzi skrywana (nawet pod powłoką swych własnych odkryć, ale także w wyniku zapomnienia, przede wszystkim jednak z powodu wyparcia i stłumienia, jeśli nie potępiających wyroków prowadzących do czyjejś śmierci) głęboka tradycja, która szukała swego materialistycznego osadzenia w filozofii spotkania (a zatem także w pewnym stopniu w atomizmie, jeśli atom rozumieć jako podstawowa jednostkę w jej „spadaniu”), to jest w radykalnym odrzuceniu wszelkiej filozofii istoty (Ousia, Essentia, Wesen) czyli Rozumu (Logos, Ratio, Vernunft), a więc Źródła i Celu, przy czym Źródło znaczy tu tyle, co antycypacja Celu w Rozumie lub w jakimś pierwotnym porządku, to znaczy w Porządku, czy to moralnym, teologicznym czy estetycznym. Rzeczona filozofia spotkania odrzuca Całość i wszelki Porządek na rzecz rozproszenia („rozsiewania” jak powiedziałby w swym język Derrida) i nieporządku. Twierdzić, że na początku istniała nicość lub chaos, to umieszczać się poniżej wszelkiego złożenia i rozplanowania, odrzucając myślenie początku w kategoriach Rozumu albo Celu, by pomyśleć je w kategoriach nicości. Na stare pytanie o to „co jest u początku świata?” ta materialistyczna filozofia odpowiada: „nicość?”, „nic!”, „zaczynam od niczego”, „nie istnieje początek, ponieważ nigdy nic nie istniało, zanim się stało”, a więc „nie istnieje żaden konieczny punkt wyjścia filozofii”, „punkt wyjścia filozofii nie jest nigdy jej pierwszym początkiem”, przeciwnie - raczej w biegu „łapie ona jadący pociag" i tylko dzięki sile swych ramion udaje jej się dostać do środka. Pociąg ten, jak heraklitejska rzeka, odwiecznie ją wyprzedza. Nie ma więc też celu czy końca ani świat, ani historia, ani filozofia, ani moralność, ani sztuka, ani polityka, itd. To tematy, które dzięki Nietzschemu, Derridzie i Deleuze'owi, dzięki empiryzmowi angielskiemu (Deleuze), Heideggerowi (i za sprawą Derridy) stały się nam znane i okazały się owocne, nie tylko w odniesieniu do umysłowości filozoficznej, ale także w różnych innych sferach (nauka, kultura, sztuka, literatura, i każdy inny sposób wyrazu egzystencji). Ta tematyka, niezależnie od pojęć, w przebraniu których występuje, istotna jest także dla naszego materializmu. Możemy ją dziś przetłumaczyć na język bardziej jasny.

Powiedzmy więc, że materializm spotkania nazwaliśmy materializmem jedynie umownie, aby zaznaczyć jego radykalną przeciwstawność względem wszelkiego idealizmu 
świadomości i rozumu, jaki by nie był jego kierunek ${ }^{5}$. Powiemy wreszcie, że materializm spotkania opiera się na pewnej interpretacji tego szczególnego stwierdzenia il y a, jest dane (,es gibt”- Heidegger) i jego rozwinięć lub implikacji, czyli: ,jest/daje” = „,zawsze już było dane nic”; to znaczy „dane jest” = „pewna rzecz”, ,zawsze już” (Heidegger 1999, 24-35); „coś”, „zawsze-już”, z którego aż dotąd czyniłem w moich esejach tak częsty użytek, co nie zawsze bywało zauważane. To stwierdzenie, będące ujęcięm (griffe) (Greifen: po niemiecku „chwyt”, „ujęcie”, Begriff. ujęcie [prise] albo pojęcie) uprzedniości każdej rzeczy względem niej samej, to znaczy względem wszelkiego początku. Powiemy więc, że materializm spotkania opiera się na tezie o prymacie pozytywności nad negatywnością (Deleuze), na tezie o prymacie odchylenia nad prostolinijnościa przebiegu (którego Początkiem jest właśnie odchylenie, a nie racja [raison]), tezie o prymacie nieporządku nad porządkiem (myślę tu o teorii „szumu”), na tezie o prymacie „rozsiania”, nad „umiejscowieniem” sensu wszelkich znaczących (Derrida) a także na tezie o erupcji porządku z samego dna chaosu, który wytwarza świat. Powiemy też, że materializm spotkania opiera się w całości na negacji Celu (Fin), na negacji wszelkiej teleologii, racjonalnej, światowej, moralnej, politycznej lub estetycznej. Powiemy też, że materializm spotkania nie jest oparty na podmiocie (czy chodziłoby o Boga, czy o proletariat), lecz na procesie, bezpodmiotowym, ale takim, który narzuca się podmiotom (jednostkowym lub innym) i bierze we władanie porządek swojego rozwoju bez dającego się wyznaczyć punktu dojścia.

Jeśli chcielibyśmy skondensować te tezy, doszlibyśmy do pewnej liczby pojęć, będących naturalnie pojęciami bez przedmiotu, pojęciami niczego i (skoro także filozofia nie ma swojego właściwego przedmiotu) kształtującymi to nic w bycie lub bytach, aż stanie się ono możliwym przedmiotem poznawczego błędu, ale także rozpoznania (i to dlatego, ostatecznie, owo nic okaże się naraz zapoznane i antycypowane). By nadać im kształt odniesiemy się do ich pierwotnej, najbardziej prostej i czystej formy, jaką przyjęły w całej historii filozofii, u Demokryta, a zwłaszcza u Epikura, zauważając przy tym, że ich dzieło nieprzypadkowo padło ofiara płomieni - to cena, jaką zapłacili, sami będąc podpalaczami filozoficznych tradycji - to ogień powstały przez tarcie, od iskry, która zapala się w najwyższych gałęziach wielkich drzew (Lukrecjusz 1968, 118) i wielkich filozofii. Byłaby to figura domagająca się swego odnowienia w każdej epoce dziejów filozofii, zawierająca następujące formy:

„Die Welt ist alles, was der Fall ist” (Wittgenstein 2004, 5) świat jest wszystkim, co „spada”, wszystkim, co „nadchodzi” (advient), „wszystkim, co jest faktem”, przez fakt (cas)

\footnotetext{
${ }^{5}$ I to dlatego, całkiem zresztą słusznie, Dominique Lecourt pozwala sobie w odniesieniu do Marksa użyć terminu „surmaterializm” w swym wyjątkowym i, naturalnie, niezauważonym przez Akademię dziele (lekceważenie, przypadające w udziale wielu, przez których poczuje się ona dotknięta) (por. Lecourt 1981; ostatnia część) [przyp. autora].
} 
rozumieć należy „kazus”: zdarzenie i przypadek naraz, to, co nadchodzi w trybie nieprzewidywalności, będącym jednak także trybem bycia.

Zatem, tak daleko wstecz, jak tylko możemy sięgnać: ,jest/daje” (Heidegger 1999, 24-35) = „zawsze dane było”, „zawsze już było dane”, to ,już” ma tu zasadnicze znaczenie, oznacza bowiem uprzedniość zachodzącej okoliczności, wszelkich form owego Fall, czyli wszelkich form bytów. To es gibt Heideggera, pierwsze „rozdanie” raczej niż to, co dane (w zależności od tego, czy chce się podkreślić jego aktywny, czy bierny aspekt), zawsze uprzednie wobec swej obecności. Innymi słowy, to prymat nieobecności nad obecnością (Derrida), nie jako zwróconej-wobec, ale jako horyzontu stale umykającego piechurowi, który poszukując swojej drogi przez równinę, zawsze znajduje jedynie kolejną równinę, która się przed nim rozciaga (zupełnie inaczej, niż w przypadku kartezjańskiego wędrowca, któremu wystarczy iść prosto, aby wyjść z lasu (por. Descartes 1981, 3-4). Świat to bowiem lasy dzikie albo wycięte, zamienione w otwarte pola, bez żadnych leśnych dróg (Holz̨wege]).

Co wydarza się w tym „świecie” bez bycia i historii, który najbardziej przypomina las Rousseau? Bo jednak „wydarza się”: bezosobowy tryb czynny/bierny (il y advient: „il”, actif(passif impersonnel). Spotkania. Zdarza się w nim to, co zdarza się w uniwersalnym deszczu Epikura, wcześniejszym niż jakikolwiek świat, jakiekolwiek bycie, jakakolwiek racja I przyczyna, zdarza się to, że coś „,się spotyka”, czy, jak u Heideggera, „,jest rzucone w” („,sa soit jete’') pierwotne przesłanie (Heidegger 2000, 31), przez cud clinamenu, który, jak wiemy, wytwarza się „nie wiadomo gdzie i nie wiadomo kiedy” i jest najmniejszym z możliwych odchyleń, to jest [ledwie] wyznaczalną nicością jakiegokolwiek odchylenia. Tekst Lukrecjusza jest dość jasny, by nazwać to, czego nie może nazwać nic na świecie, a co jest jednocześnie początkiem całego świata. W tej „nicości” odchylenia ma miejsce spotkanie atomu $\mathrm{z}$ innym atomem $\mathrm{i}$ wydarzenie to (événement) staje się nadejściem (avènement) w warunkach paralelizmu atomów, ponieważ ów raz pogwałcony paralelizm powoduje gigantyczne zderzenie i sprzężenie atomów w ich nieskończonej liczbie, skąd rodzi się świat (ten czy inny: stąd wielość światów możliwych i fakt, że sama kategoria możliwości wywodliwa jest z pojęcia pierwotnego chaosu). Stąd forma porządku i forma bytów powołanych do istnienia w tym zderzeniu, określane są przez strukturę spotkania; stąd, kiedy już do spotkania dojdzie (ale nie wcześniej), prymat struktury nad jej elementami; stąd także wreszcie powinowactwa i komplementarność elementów spotkania będących w grze, ich „sprzęgalność”, z której „bierze się” (prenne) spotkanie, to znaczy „przyjmuje formę”, dając tym samym początek Formom i Formom nowym (tak jak wodę „ścina” [prend] lód, albo tak, jak „ścina się” [prend] mleko lub majonez). Stąd też prymat „nic” nad wszelka „,formą” a także materializmu przypadku nad wszelkim formalizmem. Innymi słowy, nie jest tak, że cokolwiek wytworzyć może cokolwiek innego, [istnieja] jednak elementy, które maja się z sobą spotkać (voués à leur rencontre) i, przez powinowactwo, „przejąć” inne elementy. I to 
dlatego u Demokryta, a może nawet i u Epikura, atomy opisane są jako pokrewne, to znaczy dające się splatać jedne $z$ drugimi, odwiecznie i wiecznie.

W ten sposób raz „przejęte” lub „sprzęgnięte” atomy wkraczają do królestwa Bycia, które zapoczątkowują: ustanawiają one byty, odrębne, przypisywalne, umiejscawialne, wyposażone w tę lub inną własność (wedle czasu i miejsca), słowem - odznacza się w nich struktura Bycia lub świata, który wyznacza każdemu ze swych elementów miejsce, sens i rolę, albo lepiej - który mocuje owe elementy jako elementy czegoś (atomy jako elementy ciała, bytów, świata) w ten sposób, że atomy, nie będąc nigdy świata początkiem, są tylko pochodną swego przypisania i nadchodzenia (son assignement et avènement). By więc mówić o świecie I atomach, trzeba aby świat i atomy już istniały, co sprawia, że dyskurs o świecie jest zawsze pochodny, tak samo jak filozofia Bytu (nie będąca wcale, jak chciał Arystoteles, filozofia pierwsza), co sprawia, że wszelki dyskurs na temat filozofii pierwszej daje się ująć tylko w swej niemożliwości (jest tylko wywodliwy; por. Dopełnienie do I księgi Etyki podejmujące niemal słowo w słowo krytykę wszelkiej religii przeprowadzoną przez Epikura i Lukrecjusza). Odnosi się to nawet do filozofii materialistycznej i tłumaczy, dlaczego świadom tego Epikur nie podpisywał się pod materializmem mechanistycznym Demokryta, materializmem będącym tylko odrodzeniem, w łonie możliwej filozofii spotkania, dominującego idealizmu Porządku immanentnego wobec Chaosu.

Kiedy zasady te zostały już sformułowane, reszta, jeśli mogę tak rzec, nasuwa się sama:

1. Aby dany byt był (ciało, zwierzę, człowiek, Państwo lub Książę), trzeba aby spotkanie miało miejsce, (czas zaprzeszły złożony). By pozostać przy samym Machiavelim, spotkanie to musi mieć miejsce między tym, co może być spowinowacone, między jakąś konkretną jednostką i konkretną koniunkturą lub Fortuną - koniunktura, która sama jest połączeniem, koniunkcją, spotkaniem ustalonym, nawet jeśli wciąż w ruchu, mającym już uprzednio miejsce, odsyłającym ze swej strony do nieskończoności swych poprzedzających przyczyn, tak jak odsyła do nich, będąca ich rezultatem, zdefiniowana jednostka (dla przykładu Borgia). 2. Spotkania zachodzą jedynie między seriami bytów, wynikającymi z wielokrotnych (minimum dwóch) serii przyczyn, już jednak te dwie przyczyny zaczynają błyskawicznie proliferować, właśnie w efekcie paralelizmu albo dyfundującego zarażania (jak w niepowierzchownej frazie Bretona ,słonie są zaraźliwe”) ${ }^{6}$. Myślimy tu także o wielkim, choć zapoznanym myślicielu [Antoinie Augustinie] Cournot.

3. Każde spotkanie jest przypadkowe; nie tylko w swej genezie (nic nigdy nie gwarantuje, że do niego dojdzie), ale także w skutkach. Inaczej mówiąc - wszelkie spotkanie mogło było nie mieć miejsca, a jednak doszło do niego; to nigdy niewykluczone nieistnienie objaśnia sens

\footnotetext{
${ }^{6}$ Por. z Feuerbachem, który cytując Pliniusza Starszego stwierdza, że „słonie nie mają religii” [przypis autora].
} 
przypadkowego charakteru jego bycia. Każde spotkanie jest też przypadkowe w skutkach, których nie wyznacza żaden $z$ istniejących uprzednio elementów jego członów, dopóki nie uczyni tego samo spotkanie, ustalając zarysy i określenia bycia z niego wynikłego. Juliusz II nie wiedział, że na swojej romańskiej (romagnol) piersi wykarmi śmiertelnego wroga, tak jak nie mógł wiedzieć, że ów wróg otrze się o śmierć i w decydującym momencie biegu Fortuny wypadnie poza historię, by później śmierć rzeczywiście znaleźć, w mrocznej Hiszpani, u wrót jakiegoś nieznanego fortu. To znaczy, że żadne określenie bycia, dające się wywieść z ujęcia (prise) spotkania, nie zapowiada choćby w zarysie bycia elementów zbiegających się w spotkaniu, lecz przeciwnie, że wszelkie określenie owych elementów daje się im przypisać jedynie retroaktywnie, wychodząc od rezultatu spotkania (oraz jego nawrotu) i cofając się w stronę jego stawania się. Jeśli więc należy zgodzić się, że nie ma rezultatu bez jego stawania się (Hegel), trzeba też przyznać, że wszystko, co już się stało, określone jest tylko jako rezultat swego stawania się: przez sam nawrót (Canguilhem). To znaczy, że zamiast myślenia przygodności jako modalności albo wyjątku od konieczności, należy myśleć konieczność, jako stawanie się koniecznymi elementów przygodnych w spotkaniu. Widzimy zatem, że nie tylko świat życia (biolodzy, którzy powinni byli uważniej czytać Darwina, dopiero ostatnio zdali sobie z tego sprawę), ale także świat historii krzepnie wokół kilku szczęśliwych momentów tego „ujęcia” (prise), elementów w koniunkcji, której kształt wyznacza dane spotkanie: pewien gatunek, pewna jednostka, pewien lud. W ten właśnie sposób istnieja przypadkowi ludzie i przypadkowe „życia”, poddane przygodności śmierci (zadanej lub spotykającej je same), w ten sposób istnieja ich „dzieła” oraz w ogóle wszelkie wielkie figury świata, którym pierwotny „rzut kośćmi” nadał ich formę i w obrębie których „formę przyją” świat historii (Starożytność, Średniowiecze, Renesans, Oświecenie, itd.). Jest zatem więcej niż jasne, że ten, kto uznaje owe figury, jednostki, koniunktury lub stany świata czy to za konieczny rezultat danych przesłanek, czy za tymczasowe i antycypujące pewien Cel, myli się, zapoznaje bowiem fakt („Faktum”), że owe „prowizoryczne” rezultaty są prowizoryczne podwójnie, nie tylko dlatego, że zostana przekroczone, ale i dlatego, że wydarzyły się jedynie jako efekt „przelotnego spotkania” i że mogły były nigdy nie nadejść, jeśli nie wynurzyłyby się z pomyślnego nurtu Fortuny, dającej szczęśliwą „szansę trwania” elementom koniunkcji, które dana forma okazuje się, wskutek przypadku, organizować. Widzimy więc, że nie żyjemy w Nicości, ale że - chociaż historia nie ma Sensu (Celu wykraczającego poza jej początek i kres) - możliwy jest sens $\boldsymbol{w}$ historii, skoro rodzi się on z brzemiennego w skutki (pomyślne lub katastrofalne) spotkania, będącego także pewnym jej kierunkiem (sens).

Wynikają stąd ogromnej wagi konsekwencje dla pojęcia „prawa”. Uznajemy, że nie ma żadnego prawa, które organizowałoby spotkanie. A jednak, powiedzielibyśmy, kiedy już spotkanie „chwyci”, to znaczy, kiedy ukonstytuuje się stabilny kształt świata, jedynego świata jaki istnieje (skoro wydarzenie się danego świata wyklucza w sposób oczywisty wszelkie inne, 
możliwe światy), do czynienia mamy wtedy z pewnym światem „stałym”, którego wydarzenia i ich następstwo podlega „prawom”. Nie znaczy zatem wiele, że świat, nasz świat (innego nie znamy, poznając tylko dwa z atrybutów - myślenie i przestrzeń, ich Faktum, jak rzekłby Spinoza) narodził się w spotkaniu atomów epikurejskiego deszczu spadającego z pustki albo „Wielkiego Wybuchu”, o którym mówią astronomowie - skoro faktem jest, że do czynienia mamy z tym, a nie innym światem i faktem jest też, że jest to świat regularny, zgodny z regułami (tak jak powiedzieć można o zawodniku grającym fair, także świat gra bowiem w grę, której my sami jesteśmy przedmiotem), a więc podlegający prawom. Stąd ogromna pokusa, dosięgająca nawet tych, którzy uznaja przesłanki opisywanego przez nas materializmu spotkania, by, poszukując schronienia, ograniczyć się do badania praw wynikłych $z$ ustalonych form danego, raz zawiązanego spotkania (i powtarzania ich na różne sposoby). Ponieważ faktem, Faktum, jest również to, że istnieje w świecie porządek i że świadomość tego świata wyłania się ze świadomości jego praw (Newton) i warunków możliwości, czyli wyłącznie z poznania, a nie z samego istnienia tych praw. To oczywiście sposób by odesłać do lamusa wiekowe pytanie o początek świata (robi tak też Kant), jedynie jednak po to, by tym bardziej zaciemnić kwestię owego wtórnego spotkania, które czyni możliwym - w tym świecie - poznanie spotkania pierwszego (spotkanie pojęć i rzeczy).

No dobrze, my jednak powstrzymamy się od tej pokusy, podtrzymując tezę Rousseau, który twierdził, że umowa zawiązywana jest nad „przepaścią”, czyli że konieczność praw ustalonych w efekcie spotkania, nawet przy największej swej stałości, pozostaje nawiedzana przez radykalną niestałość, co tłumaczy problem, którego zrozumienie nastręczało nam tyle trudności, gdyż raził on nasze poczucie „zasad”, to jest problem możliwej zmienności praw. Nie idzie o to, że prawa te obowiązywałyby okresowo, a nie wiecznie (do tego punktu dochodzi w swej krytyce klasycznej ekonomii politycznej Marks, co trafnie rozpoznał jego „krytyk z Rosji”: każdej epoce historycznej inne prawa, ale na tym dość), ale o to, że moga zmienić się całkiem znienacka, ujawniając losową naturę podłoża, na którym są ufundowane, i to bez żadnej „racji”, to znaczy zrozumiałego celu. To właśnie jest ich zaskakiwaniem (surprise) (nie ma zestalenia, bez zaskoczenia) (il n'est de prise que sous la surprise), które tak bardzo uderza, gdy pomyśleć o wybuchach wielkich poczattków, zwrotach lub momentach zawieszenia w historii, czy to jednostkowej (przykładem może być szaleństwo), czy to światowej, skoro rzut kośćmi jest zawsze pewną improwizacją, skoro nowe rozdanie kart następuje bez zapowiedzi, skoro szaleństwo rozplata „elementy” i wyzwala je, umożliwiając nowe „sploty” (prises) (Nietzsche, Artaud). Z łatwością rozpoznajemy w tym jedną z fundamentalnych cech historii (i jednostek, i światów), tego „objawienia”, które z nieznanej jednostki czyni autora albo szaleńca, albo obu naraz, kiedy naraz rodzą się Hölderlinowie, Goethe'owie, Heglowie, kiedy Rewolucja Francuska wybucha i triumfuje, by później Napoleon, wcielony „Duch świata” , przedefilować mógł pod oknami 
Hegla w Jenie, kiedy Komuna upada wskutek zdrady, kiedy wybucha rok 1917 w Rosji albo rewolucja kulturalna [w Chinach], gdzie rzeczywiście niemal wszystkie „elementy”, rozmieszczone na gigantycznych przestrzeniach, zostały rozkute z kajdan, a jednak trwałe spotkanie nie zdążyło się tam zawiązać - podobnie jak 13 maja [1968 roku], kiedy robotnicy i studenci, którzy mieli się połączyć (co mogłoby z tego wyniknąć!), których równoległe szeregi przecięły się, ale bez połączenia, którzy za wszelką cenę uniknęli połączenia, zjednoczenia, wytworzenia jedności, pozostającej bez wattpienia, wciąz, i na zawsze, bezprecedensową (deszcz rozpatrywany pod względem swych skutków unikniętych). 


\section{Wykaz literatury}

Althusser, Louis. 2006. Philosophy of the Encounter Later Writings, 1978-87. Tłum. G. M. Gosharian. Londyn, Nowy Jork: Verso.

Descartes, René. 1981. Rozprawa o metodzie właściwego kierowania rozumem i poszukiwania prawdy w naukach. Tłum. Wanda Wojciechowska. Warszawa: Państwowy Instytut Wydawniczy.

Dante, Alighieri. 1977. Boska komedia. Tłum. Edward Porębowicz. Wrocław, Kraków: Zakład Narodowy im. Ossolińskich.

Heidegger, Martin. 2000. Pytanie o technike W Technika i zwrot. Tłum. Janusz Mizera. Kraków: Wyd. Baran i Suszczyński.

Heidegger, Martin 1999. Czas i bycie W Ku rzeczy myślenia. Tłum. Janusz Mizera. Warszawa: Fundacja Aletheia.

Heidegger, Martin 1996. Prayczynki do filozofii (Z wydarzenia). Tłum. Bogdan Baran, Janusz Mizera. Kraków: Wyd. Baran i Suszczyński.

Lecourt, Dominique. 1981. L'ordre des jeux. Paryż: Grasset.

Leibniz, Gottfried. 1995. Zasady natury i laski oparte na rozumie. W Gtówne pisma metafiayczne. Tłum. Stanisław Cichowicz i Juliusz Domański. Łódź: Comer.

Lukrecjusz, Tytus Karus. 1968. O rzeczymistości. Tłum. Adam Krokiewicz. Wrocław: Zakład Narodowy im. Ossolińskich Wydawnictwo Polskiej Akademii Nauk, ks. V (10911104).

Machiavelli, Niccollo. 1972. Ksiaże. W. Wybór pism. Tłum. Czesław Nanke. Warszawa: Państwowy Instytut Wydawniczy.

Malebranche, Nicolas. 2006. Traktat o moralności. Tłum. Piotr Rak. Kęty: Wydawnictwo Antyk.

Rousseau, Jan Jakub. 1956. Tray rozprany z filozofii społecznej. Tłum. Henryk Elzenberg. Warszawa: PWN.

Spinoza, Benedykt. 2008. Etyka w porz̨qdku geometrycznym dowiedz̧ona. Tłum. Ignacy Myślicki. Warszawa: Wydawnictwo PWN.

Spinoza, Benedykt. 2003. Traktaty. Tłum. Ignacy Halpern-Myślicki. Kety: Wydawnictwo Antyk.

Stirner, Max. 1995. Jedyny i jego własność. Tłum. Joanna i Adam Gajlewiczowie. Warszawa: Wydawnictwo PWN.

Wittgenstein Ludwig. 2004. Tractatus logico-philosophicus. Tłum. Bogusław Wolniewicz. Warszawa: Wydawnictwo PWN. 
Louis Althusser (1918-1990) - francuski filozof marksistowski, jeden z głównych przedstawicieli marksizmu strukturalistycznego. Absolwent, a następnie profesor filozofii w elitarnej École Normale Supérieure w Paryżu. Przez wiele dziesięcioleci działacz Francuskiej Partii Komunistycznej (PCF), z którą zerwał pod koniec życia. Był przewodnikiem ideowym młodzieży maoistowskiej i wychowawcą licznego grona uczonych. Najważniejsze prace: Pour Marx (1965; wyd. polskie: W imię Marksa, przeł. M. Herer, Warszawa 2009), Lire le Capital (z Étiennem Balibarem; 1965; wyd. polskie: Czytanie „Kapitału”, tłum. W. Dłuski, Warszawa 1975), Lenine et la philosophie (1968), Response a John Lewis (1973; wyd. polskie: W odpowiedzi Johnowi Lewisowi, tłum. A. Staroń, Warszawa 1988).

CYTOWANIE: Althusser, Louis. 2016. Podziemny nurt materializmu spotkania. Praktyka Teoretyczna 1(19): 37-62.

DOI: $10.14746 /$ prt.2016.1.3

\section{AUTHOR: Louis Althusser}

TITLE: The Underground Current of the Materialism of the Encounter

ABSTRACT: The fragment of The Underground Current of the Materialism of the Encounter presented below offers a draft of philosophical trajectory named „Materialism of encounter” or „aleatory materialism”. Its characteristic feature is the focus on contingency of preliminary constellation that organizes the very possibility of an event and its duration. he text takes as its goal the critique of the philosophical tradition that sees in materialism merely a negative of idealism that duplicates its structure and logic. The text starts with an analysis of philosophical consequences of Epicurean atomism and moves towards the discussion of a recurrent theme of void and contingency of the origin appearing in the works of such authors as Machiavelli, Spinoza, Rousseau, Marx or Heidegger. The Underground Current of the Materialism of the Encounter was published posthumously, and is based on materials that were supposed to become a basis of an unfinished book by Louis Althusser. The translation was possible thanks to courtesy of l'Institut Mémoires de l'édition contemporaine (IMEC).

KEYWORDS: atomism, clinamen, contingency, materialism, Marx, Heidegger, Machiavelli, Spinoza, Hobbes, Rousseau. 